\title{
Adriana Merta-Staszczak
}

Politechnika Wrocławska

Studium Nauk Humanistycznych i Społecznych

e-mail: adriana.merta-staszczak@pwr.edu.pl

\section{CZYNNIKI WPLYWAJĄCE NA STAN ZACHOWANIA OBIEKTÓW ZABYTKOWYCH PO 1945 ROKU NA DOLNYM ŚLĄSKU}

\section{FACTORS AFFECTING THE STATE OF PRESERVATION OF HISTORIC BUILDINGS SINCE 1945 IN LOWER SILESIA}

DOI: $10.15611 /$ sie.2016.1.02

JEL Classification: N9, N5, P32, Q1, Q13, Q15, R1, R3, Z32

Streszczenie: Zabytkowe zespoły rezydencjonalne, złożone z zamków, dworów, pałaców, parków i folwarków, stanowią ważną część dziedzictwa kulturowego Dolnego Śląska. Jest to zbiór liczny i zróżnicowany pod względem wartości historycznych oraz estetycznych. Jednakże po 1945 roku nie został on objęty specjalną ochroną i podlegał wielu czynnikom niekorzystnie wpływającym na stan jego zachowania. Dotyczyło to zwłaszcza budynków niezagospodarowanych i pozbawionych odpowiedzialnych właścicieli. Największe zniszczenia w historycznych obiektach były wynikiem działalności człowieka, na którą składały się zarówno celowa dewastacja, jak i brak przeprowadzania należytych remontów i renowacji zgodnych z zasadami konserwatorskimi, a także niewłaściwe użytkowanie, często prowadzące do pożarów. Destrukcja zabytków intensyfikowana była przez zjawiska atmosferyczne i przyrodnicze: deszcze, wichury, wysokie temperatury, mrozy i powodzie.

Słowa kluczowe: Dolny Śląsk, zabytki, zespoły rezydencjonalne, Agencja Nieruchomości Rolnych.

Summary: Historical residential complexes containing castles, mansions, palaces, parks and farms, are an important part of the cultural heritage of Lower Silesia. It is a big collection diversified in terms of historical and aesthetical values. Despite this, after 1945 they were not covered by a special protection and were subject to a number of factors adversely affecting their state of preservation. This was especially true of undeveloped buildings and of those lacking responsible owners. The biggest damage done in historical objects was the result of human activities, which consisted of both intentional devastation and failure to carry out adequate repair and renovation in accordance with the principles of conservation. The destruction of monuments was intensified by the atmospheric phenomena such as rain, high winds, high temperatures, frost, floods and fire.

Keywords: Lower Silesia, monuments, residential complexes, Agricultural Property Agency. 


\section{Wstęp}

Zabytkowe założenia rezydencjonalne, które pojawiły się na ziemiach polskich najpóźniej na początku XIII wieku' ${ }^{1}$ aktualnie stanowią na Dolnym Śląsku ${ }^{2}$ liczną grupę obiektów objętych ochroną konserwatorską. Wśród nich znajdują się zamki, pałace, dwory oraz folwarki, stanowiące często przykłady architektury o wyjątkowych cechach historycznych i estetycznych. W roku $2011 \mathrm{w}$ rejestrze zabytków dolnośląskich znajdowało się 7690 budynków stanowiących 12\% wszystkich obiektów w kraju3 . W grupie tej sklasyfikowano 99 zamków, 481 pałaców oraz 191 dworów ${ }^{4}$. Nie oznaczało to jednak, że wszystkie przetrwały do czasów współczesnych. Całkowicie zniszczono 87 z nich, 21 utraciło cechy zabytkowe, a aż 286 oznaczono jako jednostki zagrożone.

Tematowi zabytkowych obiektów poświęcono wiele powojennych opracowań naukowych z zakresu archeologii, architektury i historii; wymienić tu należy m.in. liczne rozprawy Krzysztofa Esymontta, Olgierda Czernera, Jana Pruszyńskiego, Leszka Kajzera, Bohdana Guerquina, ale również prace późniejsze: Małgorzaty Chorowskiej i Renaty Gubańskiej oraz Romualda Łuczyńskiego. Poruszały one problematykę badań nad zabytkową zabudową i założeniami rezydencjonalnymi, zabytku jako dzieła sztuki, kwestii powstania takich obiektów, ich historii, stylów architektonicznych, funkcji i wykorzystania, ale również uwzględniały kwestie konserwacji zabytków i ich zachowania jako ważnego elementu historii, tradycji i kultury. W ostatnich latach przybyło również publikacji dotyczących przestępczości przeciwko dziedzictwu kulturowemu. Przybiera ono różne formy: nielegalnego wywozu dzieł sztuki, fałszerstw, kradzieży, niszczenia i grabieży stanowisk archeologicznych oraz dewastacji zabytkowej architektury, w tym pałaców, dworów, zamków, folwarków i innych budynków objętych ochroną konserwatorską. Jednak o ile w przypadku zabytków ruchomych ${ }^{5}$ działalność taka jest oczywistym naruszeniem prawa, to straty wywołane zniszczeniem obiektów architektonicznych są trudne do

${ }^{1}$ M. Chorowska, 2003, Rezydencje średniowieczne na Ślasku. Zamki, pałace, wieże mieszkalne, Wrocław, s. 303.

${ }^{2}$ Po 1945 roku tzw. Ziemie Odzyskane podzielono na cztery okręgi administracyjne, a jednym z nich był Dolny Śląsk. W 1956 roku wydzielono 17 województw, w tym wrocławskie. Natomiast w 1975 roku uchwalono kolejną zmianę w podziale administracyjnym. Zlikwidowano powiaty oraz do 49 zwiększono liczbę województw. Z dotychczas istniejącego województwa wrocławskiego wydzielono cztery nowe (wrocławskie, legnickie, wałbrzyskie i jeleniogórskie). W 1999 roku zostały one ponownie połączone w województwo dolnośląskie.

${ }^{3}$ Raport roczny Narodowego Instytutu Dziedzictwa, 2011, Warszawa, s. 51.

${ }^{4}$ Obiekty nieruchome wpisane do rejestru zabytków, Narodowy Instytut Dziedzictwa, ww.nid.pl.

${ }^{5}$ Ważnym problemem zachowania zespołów rezydencjonalnych są losy ich zabytkowego wyposażenia, m.in. mebli, dzieł sztuki i księgozbiorów. Jeśli nie uległy zniszczeniu podczas działań wojennych i grabieży dokonywanych przez Armię Czerwoną, były wynoszone wraz z opuszczaniem budynków przez ostatnich użytkowników lub kradzione, kiedy budynek był już pusty. Wrocławski oddział ANR przejmował zabytki zazwyczaj pozbawione cennego wyposażenia. 
oszacowania. Jako ciekawe źródło wiedzy wymienić należy artykuły Olgierda Jakubowskiego oraz wydawnictwa Narodowego Instytutu Dziedzictwa. Natomiast w kwestii rejestru i ewidencji dolnośląskich zabytków, stanu zachowania konkretnych obiektów oraz przyczyn ich zniszczeń najważniejszymi materiałami są archiwa przejęte z byłych Państwowych Gospodarstw Rolnych (PGR) przez wrocławski oddział Agencji Nieruchomości Rolnych (ANR OT we Wrocławiu) ${ }^{6}$ oraz dokumentacja zgromadzona w Archiwum Wojewódzkiego Urzędu Ochrony Zabytków.

Zmieniające się systemy społeczno-polityczne często były źródłem zniszczeń w obiektach o wartości historycznej i zabytkowej. W ich wyniku odrzucano spuściznę poprzednich pokoleń lub innych narodów, krytykowano ją i otaczano pogardą ${ }^{7}$. Zjawisko to występowało na całym świecie, począwszy od czasów starożytnych (palenie ksiąg proroczych w Rzymie, niszczenie pogańskich świątyń, posągów i obrazów) ${ }^{8}$. Również w Polsce po 1945 roku, w efekcie przejścia gospodarki od wolnorynkowej do uspołecznionej, zabytkowe zespoły, w tym również założenia rezydencjonalne, odniosły duże straty ${ }^{9}$. Wcześniej wyróżniały się one wielkością i formą oraz dominowały, szczególnie w krajobrazie wiejskim, nad pozostałymi zabudowaniami ${ }^{10}$. Jednak po 1945 roku utraciły swoje dotychczasowe funkcje centralnych punktów dawnych majątków: ośrodków administracyjnych, reprezentacyjnych i kulturalnych. Wojna i rewolucja społeczna, polegająca na wymianie niemal całej ludności z terenów Ziem Zachodnich i Północnych, skutkowała przerwaniem ciągłości kultury i tradycji tych regionów. To również miało wpływ na dalsze losy historycznych rezydencji. Wobec zmieniającej się sytuacji w kraju obiekty zabytkowe, które nie zostały przeznaczone na szkoły lub inne budynki użyteczności publicznej, zostały w większości pozostawione bez właścicieli i ochrony. Ich stan techniczny pogarszał się, a główne tego przyczyny były rozmaite i często występowały jednocześnie, znacznie utrudniając działania rewaloryzacyjne. Były to: ustawodawstwo, niszcząca działalność ludzka i warunki atmosferyczne, a także czas działający na niekorzyść każdego budynku, nadmierny rozwój aglomeracji otaczających zespoły zabytkowe, komunikacja niedostosowana do zabytkowych układów i zanieczyszczona atmosfera ${ }^{11}$. W dalszej części artykułu zostały omówione trzy pierwsze, ale także najważniejsze elementy.

${ }^{6}$ W latach 1991-2003 funkcjonowała pod nazwą Agencja Własności Rolnej Skarbu Państwa.

7 J. Świerczyński, 1986, Grabieżcy kultury i fatszerze sztuki, Warszawa, s. 230-231.

8 Tamże.

${ }^{9}$ O. Czerner, 2000, Zabytki Ślaska w Polsce dyktatury proletariatu, [w:] Badania i ochrona zabytków w Polsce w XX wieku: materiały z konferencji naukowej zorganizowanej staraniem Wydziału Architektury Politechniki Warszawskiej, Generalnego Konserwatora Zabytków i Towarzystwa Opieki nad Zabytkami w stulecie urodzin Profesora Jana Zachwatowicza w dniu 4 marca 2000 roku, Tomaszewski A. (red.), s. 60.

${ }^{10}$ R. Gubańska, 2009, Budynki i budowle dolnoślaskich folwarków, Wrocław, s. 7.

${ }^{11}$ E. Małachowicz, 1994, Konserwacja i rewaloryzacja architektury w zespołach i krajobrazie, Wrocław, s. 358. 


\section{Ochrona zabytków w Polsce a ustawodawstwo}

Po 1945 roku w Polsce obowiązywało Rozporządzenie Prezydenta Rzeczpospolitej z dnia 6 marca 1928 roku, w którym określono, iż za zabytek uznać można „budowle zarówno murowane, jak i drewniane, wraz z wszelkimi szczegółami architektury i dekoracji ściennej oraz z otoczeniem”, a także „ruiny budowli”" ochronie na skutek wydanego przez władze konserwatorskie orzeczenia stwierdzającego wartość zabytkową. Mimo funkcjonującego prawa i obowiązku ich zachowania, obiekty te, ich odbudowa, utrzymanie i wykorzystanie stanowily trudny do rozwiązania problem, ale również obciążenie dla lokalnej administracji i instytucji. Zostały one, wraz z gruntami, które kiedyś były częścią majątków, upaństwowione i rozdysponowane między różnymi resortami. Największa ich liczba została przekazana Ministerstwu Rolnictwa, które z kolei nadzór nad nimi powierzyło, tworzonym na terenie całego kraju, Państwowym Gospodarstwom Rolnym ${ }^{13}$. Podstawowym celem tych działań było uzupełnienie braku budynków mieszkalnych i socjalnych. W tym czasie powstał projekt ustawy (tzw. nieborowskiej) przedstawiony w 1957 roku ministrowi kultury i sztuki ${ }^{14}$. Zakładano w nim m.in. nałożenie odpowiedzialności za zniszczenie zabytków na urzędników i użytkowników, jednak nie został on ostatecznie rozpatrzony przez sejm. Dopiero w 1962 roku, kiedy proces zagospodarowywania zabytków nadal trwał, wprowadzono nową ustawę dotyczącą opieki nad nimi. Rozpoczynała się ona od stwierdzenia, że dobra kultury należą do całego narodu i powinny być chronione przez wszystkich obywateli ${ }^{15}$. Nieco dokładniej niż w rozporządzeniu z 1928 roku opisano w niej przedmiot opieki konserwatorskiej. Były to m.in. „dzieła budownictwa, urbanistyki i architektury, niezależnie od ich stanu zachowania, jak historyczne założenia urbanistyczne miast i osiedli, parki i ogrody dekoracyjne, cmentarze, budowle i ich wnętrza wraz z otoczeniem oraz zespoły budowlane o wartości architektonicznej, a także budowle mające znaczenie dla historii budownictwa"16. Mimo że przepisy dotyczące ochrony prawnej obiektów zabytkowych istniały, w praktyce do końca lat 80 . XX wieku na ogół nie były one skrupulatnie przestrzegane. W szczególności dotyczyło to zamków, pałaców, dworów i folwarków na tzw. „Ziemiach Odzyskanych”, do których ludność napływowa nie była historycznie i kulturowo przywiązana. Właściciele, mieszkańcy czy sąsiedzi takich zespołów w większości nie robili nic, by je odpowiednio zabezpieczyć i nie czuli się

12 Rozporządzenie Prezydenta Rzeczpospolitej z dnia 6 marca 1928 r. o opiece nad zabytkami, Dz.U. 1928 nr 29, poz. 265.

13 Przebudowa ustroju rolnego była podstawowym zamierzeniem władz w okresie powojennym, a hasła kolektywizacji wsi nasilały się szczególnie po 1947 roku. W myśl głoszonej zasady o przewadze wieloobszarowych gospodarstw uspołecznionych nad sektorem chłopskim w 1949 roku zaczęto tworzyć Państwowe Gospodarstwa Rolne.

${ }_{14}$ J. Pruszyński, 1996, Stan i potrzeby regulacji prawnej ochrony zabytków w Polsce, Ochrona Zabytków, nr 49/3, s. 295.

${ }^{15}$ Ustawa o ochronie dóbr kultury, Dz.U. $1962 \mathrm{nr}$ 10, poz. 48.

16 Tamże. 
zobowiązani do ich właściwego utrzymania. Odpowiedzialność ta spoczywała tylko formalnie na służbach konserwatorskich i instytucjach państwowych. Brakowało zintegrowanych działań na rzecz dziedzictwa, ale też kompleksowej dokumentacji konserwatorskiej zniszczonej lub wywiezionej podczas II wojny światowej. Ta, tworzona do końca lat 80 . XX wieku, obejmowała przede wszystkim zabytki najcenniejsze ${ }^{17}$.

Taka sytuacja obiektów zabytkowych utrzymywała się jeszcze długo po odstąpieniu od gospodarki centralnie planowanej i zmianie ustrojowej w Polsce. Popegeerowski majątek, a wraz z nim zabytkowe zespoły, ponownie przejęte zostały do Skarbu Państwa, ale tym razem dozór nad nim objęła Agencja Własności Rolnej Skarbu Państwa ${ }^{18}$. Pod zarząd jej wrocławskiego oddziału trafiło przynajmniej 683 obiektów ${ }^{19}$. Były to: rezydencje, parki, zabudowa folwarczna, pojedyncze elementy zabytkowe (takie jak herb von Magnis czy balustrada schodów z Ołdrzychowic), a także zabytki o charakterze funeralnym (m.in. mauzoleum w Szczepowie w gminie Żukowice) oraz stanowiska archeologiczne ${ }^{20}$. Wiele budynków było zamieszkałych przez byłych pracowników państwowych gospodarstw i ich rodziny, co znacznie utrudniało proces ich dalszego zagospodarowania. Natomiast stan techniczny przejętych obiektów architektonicznych był bardzo zróżnicowany, dlatego Agencja w pierwszych latach swojej działalności wyznaczyła zespoły specjalistów do skatalogowania obiektów, określenia stopnia ich zachowania oraz możliwości adaptacji do nowych celów ${ }^{21}$. Ustalono, iż obiekty w stanie dobrym stanowią jedynie 1,6\% ogólnej ich liczby. Były to m.in. pałac w Nowoszycach (gmina Oleśnica), pałac w Wielkiej Lipie (gmina Oborniki Śląskie) czy dwór w Siemisławicach (gmina Przeworno). Zidentyfikowano przynajmniej kilkanaście budynków uszkodzonych oraz obiekty zniszczone. Te ostatnie łącznie stanowiły około $6 \%$ wszystkich budynków zabytkowych w zasobie Agencji. Pośród nich wyróżniono pięć zupełnie unicestwionych. Były to pałac i oficyna w Starych Rochowicach (gmina Bolków), rezydencja w Barcinku (gmina Stara Kamienica) i Kromolinie (gmina Żukowice) oraz park w Sobocie (gmina Lwówek Śląski). Część przejętych obiektów nie rokowała żadnych szans na możliwości ich zagospodarowania. $\mathrm{W}$ takich przypadkach rezygnowano z ich remontu i ograniczano się do zabezpieczenia budynku. Jednym z takich przykładów był XIX-wieczny pałac we Wziąchowie Małym (gmina Milicz). Po przejęciu przez

17 B. Nowak-Obelinda, 2015, Czy system ochrony i opieki nad zabytkami zapewnia prawidlowe zagospodarowanie i konserwację zabytków nieruchomych w Polsce?, [w:] Zabytek zadbany. Co to znaczy?, Liżewska I. (red.), Warszawa, s. 11.

${ }_{18}$ Od 2003 r. funkcjonowała pod nazwą: Agencja Nieruchomości Rolnych.

${ }^{19} \mathrm{~W}$ liczbie tej mieszczą się również całe zespoły zabytkowe złożone z wielu budynków, ponieważ w dokumentacji Agencji Nieruchomości Rolnych Oddział Terenowy we Wrocławiu (ANR OT Wrocław) były one wpisane jako jeden element.

${ }^{20}$ Szerzej omówione w: A. Merta-Staszczak, 2014, Rezydencje w procesie zagospodarowania nieruchomości Skarbu Państwa na Dolnym Śląsu w latach 1989-2011, Torun.

${ }^{21}$ Całość sporządzonych w 1995 roku ankiet obiektów zabytkowych nie zachowała się. 
PGR budynek był użytkowany niezgodnie ze swoim przeznaczeniem. Przeprowadzano w nim jedynie drobne prace zabezpieczające i adaptacyjne, montując m.in. prowizoryczne ścianki działowe ${ }^{22}$. Kiedy nieruchomości ponownie upaństwowiono, pałac znajdował się w stanie ruiny, natomiast park wokół niego był bardzo zniszczony i częściowo przekształcony ${ }^{23}$. Najpilniejszymi pracami remontowymi, mającymi poprawić stan zachowania budynku, były: naprawa ścian i stropów, remont kapitalny więźby dachowej i położenie nowego pokrycia dachu ${ }^{24}$. Jego średni stan zużycia oceniono na $76 \%$ (fundamenty $30 \%$, ściany konstrukcyjne $80 \%$, stropy $80 \%$, schody $90 \%$, dach $70 \%$, ściany działowe $80 \%$, podłogi i posadzki $100 \%$, stolarka okienna i drzwiowa $100 \%$, tynki wewnętrzne $70 \%$, elewacje $70 \%)^{25}$. Stan zachowania pogarszały liczne kradzieże drewna i elementów ozdobnych oraz wycinanie krokwi ${ }^{26}$.

Ostatnią i najliczniejszą grupę w przejętych zespołach stanowiły obiekty zaniedbane. Wymagały one napraw, takich jak: osuszenie murów, uszczelnienie dachu, uzupełnienie tynków wewnętrznych i zewnętrznych, naprawy elementów blacharskich czy prac mających na celu uporządkowanie bezpośredniego otoczenia zespołu lub pojedynczych obiektów. Jednakże w stanie dostatecznym pozostawały najważniejsze elementy konstrukcji: mury, sklepienia i stropy. Przy dobrej woli i zaangażowaniu właścicieli budynki te mogły być jeszcze uratowane i adaptowane na cele mieszkaniowe, hotelowe czy konferencyjne.

Równocześnie z powstaniem Agencji, w 1991 roku, przyjęto ustawę o gospodarowaniu nieruchomościami rolnymi Skarbu Państwa, która regulowała sytuację dawnych majątków ziemskich. Rozwiązaniem miała być ich intensywna restrukturyzacja i prywatyzacja oraz szybkie przeniesienie odpowiedzialności za mienie z instytucji państwowych na nowych właścicieli (gminy, firmy, fundacje, osoby prywatne). Do końca lat 90. XX wieku wrocławski oddział Agencji sprzedał 74 rezydencje, część wraz z zabudową gospodarczą. Działania te nie przyniosły jednak oczekiwanych efektów związanych z zachowaniem zabytkowej architektury, ponieważ nowi właściciele nie zawsze byli zainteresowani zabezpieczeniem i odbudową pałaców czy dworów. Podczas gdy Agencja nadal była posiadaczem najliczniejszego zbioru historycznych rezydencji, w 2003 roku uchwalono nową ustawę określającą przedmiot, zakres i formy ochrony zabytków oraz opieki nad nimi ${ }^{27}$. Ważnym jej punktem było uwzględ-

${ }^{22}$ P. Godlewski, 1990, Karta ewidencyjna zabytków architektury $i$ budownictwa, pałac we Wziqchowie Matym, WUOZ we Wrocławiu, Wrocław, s. 4. Skrót WUOZ, którym posługuje się autorka w niniejszym przypisie, w kolejnych przypisach i pozycjach wyszczególnionych w spisie literatury, jest akronimem nazwy Wojewódzki Urząd Ochrony Zabytków we Wrocławiu.

${ }^{23}$ J. Matusiak, 1990, Karta ewidencyjna zabytków architektury i budownictwa, zespót folwarczny we Wziachowie Małym, WUOZ we Wrocławiu, Wrocław, s. 3.

${ }^{24}$ Tamże.

25 J. Malicki, M. Delineszew, W. Antas, 2003, Inwentaryzacja budowlana z opiniq techniczna dworu mieszkalnego, Wziachowo Małe, Gmina Milicz, WUOZ we Wrocławiu, Wrocław, s. 8-12.

26 Tamże.

27 Ustawa z dnia 23 lipca 2003 r. o ochronie zabytków i opiece nad zabytkami, Dz.U. 2003 nr 161, poz. 1568. 
nienie obowiązków właścicieli, które polegały m.in. na zabezpieczeniu i utrzymaniu zabytku w jak najlepszym stanie i korzystaniu z niego przy zachowaniu jego wartości, a także na podejmowaniu działań mających na celu popularyzowanie wiedzy o zabytku i jego znaczeniu historycznym oraz kulturowym.

\section{Zniszczenia wynikające z działalności czlowieka}

Działania na rzecz ochrony szeroko pojętego dziedzictwa kulturowego na ziemiach polskich rozpoczęto w XIX wieku. Dopiero od tego czasu zaczęto podejmować świadome prace związane z zachowaniem starych budynków ${ }^{28}$. Stopniowo budowano również świadomość wartości dziedzictwa kulturowego i narodowego. Jego regres i wynikający z tego niszczący wpływ użytkowników, mieszkańców, osób odpowiedzialnych za zachowanie obiektów zabytkowych oraz brak odpowiednich prac konserwatorskich i zabezpieczających uwidocznił się zwłaszcza w okresie po 1945 roku do końca lat 80 . XX wieku. Po II wojnie światowej podejmowano próby systematyzowania działań na rzecz ochrony zabytków. Do połowy lat 50. XX wieku wyróżnić można trzy etapy w polityce zachowania i opieki nad dziedzictwem w formie historycznej architektury ${ }^{29}$ :

- 1944-1946 - okres drobnych zabezpieczeń,

- 1947-1949 - przeznaczanie coraz większych środków na „zabezpieczenie stałe” obiektów, oznaczające doprowadzenie ich do stanu surowego zamkniętego,

- 1950-1954 - ustanowienie hierarchii obiektów z uwzględnieniem potrzeb społecznych wobec zbyt małych nakładów finansowych na ratowanie zabytków.

Działania, ograniczone do prowizorycznych zabezpieczeń, jak i bardziej zintensyfikowane prace prowadzące do remontów całych budynków, nie były wystarczające, ponieważ często odbudowa ta miała charakter fragmentaryczny, żywiołowy i niejednokrotnie odstępowano od naukowych zasad rekonstrukcji ${ }^{30}$. Czynnościom związanym z odbudową w pierwszej kolejności podlegały obiekty zlokalizowane w dużych ośrodkach miejskich lub te o wyjątkowych walorach, usytuowane w pobliżu miast. W tym czasie dopiero zaczęły się kształtować nowe służby konserwatorskie, których obowiązkiem było nadzorowanie właściwego wykonywania takich napraw. W lutym 1945 roku jako jednostkę Ministerstwa Kultury i Sztuki powołano Naczelną Dyrekcję Muzeów i Ochrony Zabytków, a prace inwentaryzacyjne i dokumentacyjne prowadził Instytut Historii Sztuki i Inwentaryzacji Zabytków ${ }^{31}$. We Wrocławiu

${ }^{28}$ M. Barański, 1999, Świadomość a ochrona zabytków, [w:] Zabytki i społeczeństwo. Czynnik społeczny w ochronie zabytków w warunkach reformy samorządowej, Gutkowska K., Kobyliński Z. (red.), Warszawa, s. 62.

${ }_{29}$ M. Krasocki, 1955, Dziesięć lat pracy konserwatorskiej w liczbach, Ochrona Zabytków, R.8, nr 2, s. 74.

${ }^{30}$ O. Czerner, 2004, Architektury istnienie i zachowanie - z szuflady Profesora, Wrocław, s. 185.

31 J.E. Dutkiewicz, 1964, Dwadzieścia lat ochrony zabytków w Polsce Ludowej, Ochrona Zabytków, nr 17/2, s. 9. 
powołano Wrocławską Dyrekcję Odbudowy, a pierwszego wojewódzkiego konserwatora zabytków mianowano pod koniec $1946 \mathrm{roku}^{32}$. Służby te zmagały się z wieloma problemami wpływającymi na efektywność ich działań: brakiem odpowiedniej liczby specjalistów z zakresu historii sztuki i architektury, niewystarczającymi środkami finansowymi wobec stopnia zniszczeń obiektów zabytkowych, ale także podporządkowaniem, również $\mathrm{w}$ kwestiach merytorycznych, centralnym organom władzy ${ }^{33}$. Te ostatnie działalność konserwatorów postrzegały często jako „hamulec postępu" 34 w rozbudowie infrastruktury i modernizacji miast i wsi.

Jednocześnie z wysiłkami związanymi z ochroną zabytków przyjęto uchwałę Prezydium Rządu z dnia 20 sierpnia 1955 roku $^{35}$, która wpłynęła na znaczne pogorszenie ich sytuacji. Miała ona na celu usunięcie zniszczeń wojennych z miast i osiedli, zlikwidowanie ruin i obszarów zagruzowanych, ale również pozyskiwanie oraz dalsze wykorzystanie materiałów budowlanych do odbudowy domów. W wykazach określających wykonanie uchwały znaleźć się miały budynki uszkodzone i zakwalifikowane do odbudowy, zniszczone i przeznaczone do rozbiórki oraz obiekty zgłoszone przez służby konserwatorskie. W tym ostatnim przypadku o zniszczeniu lub odrestaurowaniu obiektów zabytkowych decydować miał minister kultury i sztuki w porozumieniu z prezesem Komitetu do spraw Urbanistyki i Architektury. Należy zaznaczyć, że wykonanie działań związanych z tą akcją było premiowane. Dodatkowe wynagrodzenie uzależnione było od ilości pozyskanej cegły i innych materiałów, usuniętego gruzu oraz liczby uporządkowanych terenów. Zakończenie prac planowano na koniec grudnia 1962 roku w przypadku większości województw, a rok później we Wrocławiu i na terenie powiatu jeleniogórskiego ${ }^{36}$. Na skutek przeprowadzonej akcji zniszczeniu uległy obiekty zabytkowe w miastach, a najsłynniejszym zdarzeniem, które zwróciło uwagę władz na ten problem, była sprawa Nysy. Rozebrano tam zabytkowe kamienice, niszcząc historyczny układ miasta. Urzędy konserwatorskie dostrzegały i potępiały problem powtarzających się na terenie całego kraju ,niekontrolowanych i dzikich akcji rozbiórkowych" ${ }^{37}$ zabytków, ale jednocześnie podkreślano, że władz administracyjnych nie stać na utrzymanie wszystkich zabytkowych budynków. W związku z tym na terenie województwa wrocławskiego $\mathrm{w}$ latach 70. XX wieku zdecydowano o rozbiórce około 300 takich obiektów ${ }^{38}$. Tym

${ }^{32}$ M. Przyłęcki, 1979, Odbudowa, konserwacja i ochrona zabytków architektury na Dolnym Ślasku w latach 1945-1978, Ochrona Zabytków, nr 32/4, s. 267.

${ }_{33}$ O. Czerner, 1974, W trzydziestolecie powojennej opieki nad zabytkami, Ochrona Zabytków, nr 27/3, s. 171-173.

${ }^{34}$ J. Pruszyński, 1989, Ochrona zabytków w Polsce, Warszawa, s. 185.

${ }^{35}$ Uchwała nr 666 Prezydium Rządu z dnia 20 sierpnia 1955 r. w sprawie planowanej akcji usunięcia pozostałości zniszczeń wojennych w miastach i osiedlach.

${ }^{36}$ Uchwała nr 417 Rady Ministrów z dnia 8 grudnia 1960 r. w sprawie zakończenia prac związanych z usuwaniem pozostałości zniszczeń wojennych.

${ }^{37}$ Stenogram narady kierowniczej kadry kulturalnej województwa wrocławskiego, Wrocław 1972, Archiwum Państwowe we Wrocławiu, Prezydium WRN we Wrocławiu, syg. IX/8, s. 52.

38 Tamże. 
bardziej na terenach wiejskich, gdzie nie respektowano wytycznych służb konserwatorskich, dochodziło do licznych dewastacji. Mimo prób ograniczenia zniszczeń oraz skierowywanej do ludności akcji informacyjnej „Chrońmy zabytki”, historyczne budynki, a zwłaszcza rezydencje, były nadal traktowane jak symbol dawnych, potępianych układów społecznych oraz własności niemieckiej. Władze lokalne usprawiedliwiały dewastacje i rozbiórki zabytków, argumentując, że są one „obce narodowo", kulturowo, religijnie lub są przeszkodą w rozwoju wsi ${ }^{39}$. Innym problemem było to, iż niejednokrotnie nie wiedziano, że przeznaczony do wyburzenia budynek przedstawia jakąkolwiek wartość historyczną ${ }^{40}$.

Działania na rzecz ochrony były niewystarczające, ponieważ nie posiadano wtedy ani pomysłów, ani planów na całościowe rozwiązanie kwestii zachowania budynków. Ostatecznie wiele „niepotrzebnych” zabytkowych zespołów zostało oddanych państwowym przedsiębiorstwom rolnym. W ich strukturach dostosowano je do niemal wszystkich możliwych i potrzebnych, z punktu widzenia kierownictwa państwowych gospodarstw, funkcji: przede wszystkim na biura i mieszkania dla kadry zarządzającej i pracowników stałych lub sezonowych oraz ich rodzin. W pozostałych urządzano świetlice, stołówki, przedszkola, szkoły, internaty (pałac Boleścin), magazyny (pałac w Strużynie), składy i stolarnie (pałac w Czerczyńcach). Wnętrza w gorzej zachowanych obiektach przeznaczano również na kurniki, chlewnie i obory lub pozostawiano je bez opieki i nadzoru. O tym, w jaki sposób użytkowano rezydencje, świadczy przykład pałacu w Sokolnikach (gmina Łagiewniki), który powstał prawdopodobnie około 1736 roku. Po 1945 roku urządzono w nim mieszkania oraz biura. W latach 80 . XX wieku, w związku z planami przebudowy obiektu na blok mieszkalny dla pracowników gospodarstwa rolnego, zlikwidowano biura, a lokatorów wykwaterowano. Rozpoczęto prace budowlane, ale nigdy ich nie ukończono, a zgromadzone materiały budowlane rozkradziono ${ }^{41}$. Rezydencję opuszczono i od tamtego czasu popadała ona w ruinę. Innym przykładem porzuconego przez PGR zabytku był pałac w Ozorowicach (gmina Wisznia Mała), którego dewastacja rozpoczęła się w latach 70 . XX wieku, a na początku lat 80 . XX wieku dobrze zachowane pozostawały jedynie fundamenty. Ściany w większości były w złym stanie (spękania, zawilgocenie, ubytki w tynku, rozbity taras) i we fragmentach zawalone, wszystkie podłogi zostały zerwane, nie pozostał nawet ślad po dawnym wyposażeniu ${ }^{42}$. W takich przypadkach służby konserwatorskie lub naczelnicy zakładów rolnych niejednokrotnie interweniowali, nakazując podjęcie remontów i zabezpieczeń. Jednak najczęstszą reakcją na pisma było dokonywanie prac w minimalnym zakresie. Ogra-

39 J. Pruszyński, 1992, Tradycja i postęp (ochrona zabytków na wsi), Ochrona Zabytków, nr 45/1-2, s. 33 .

40 Stenogram narady kierowniczej..., s. 56.

${ }^{41}$ I. Gąsior, 1995, Karta ewidencyjna zabytków architektury i budownictwa, Pałac w Sokolnikach, WUOZ we Wrocławiu, Wrocław, s. 4.

${ }^{42}$ E. Marcinkowska, B. Uszałowicz, 1983, Karta ewidencyjna zabytków architektury i budownictwa, Pałac w Ozorowicach, WUOZ we Wrocławiu, Wrocław, s. 2. 
niczały się one do usunięcia gruzu z pomieszczeń pałaców czy dworów oraz oczyszczenia lub usunięcia śmieci z parku otaczającego zabytek. Najczęściej nie wykonywano jednak zaleceń konserwatorskich, a dokumentacje dotyczące planów odbudowy szybko ulegały dezaktualizacji. Tłumaczono to brakiem czasu, ekip remontowych oraz materiału, a także ważniejszymi i pilniejszymi potrzebami dotyczącymi zabezpieczeń budynków inwentarskich.

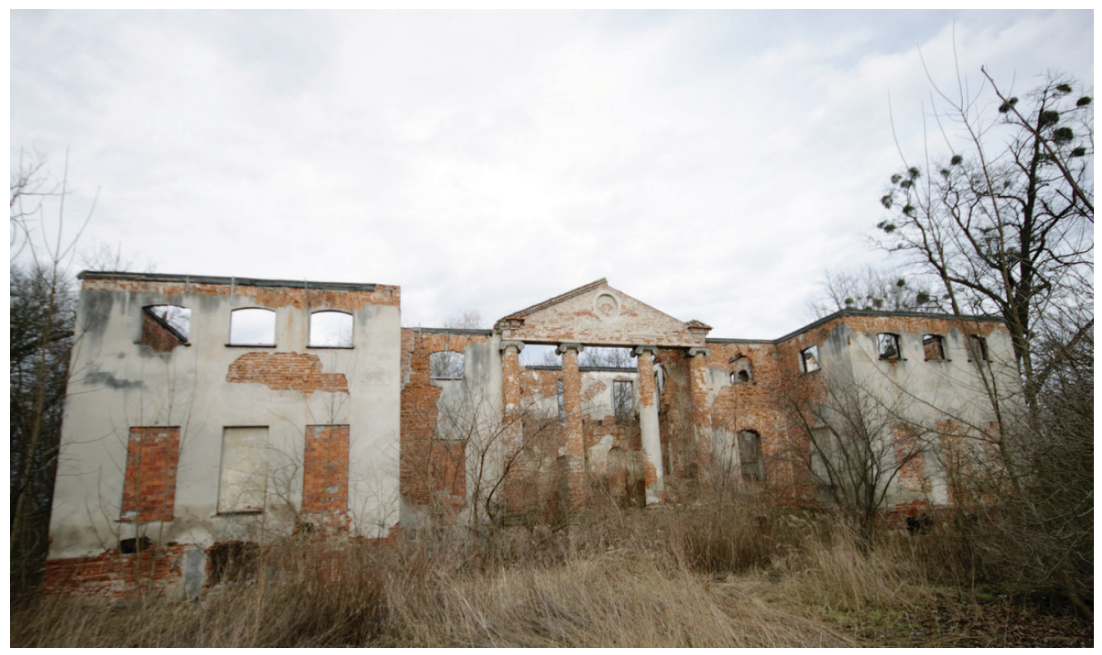

Fot. 1. Pałac w Ozorowicach

Źródło: zbiory własne.

W obiektach adaptowanych na cele mieszkalne czy biurowe przeprowadzano inwazyjne i intensywne remonty, najczęściej niezgodne z zasadami konserwatorskimi. Ich efektem było bezpowrotne likwidowanie cech zabytkowych. Przykładem takich wielokrotnych modyfikacji był pałac w Dalkowie (gmina Gaworzyce). W latach 70. XX wieku zadecydowano, że na parterze i pierwszym piętrze powstaną biura z zapleczem sanitarnym, przedszkole dla 30 dzieci z zapleczem kuchennym, klubokawiarnia zlokalizowana w najstarszej części budynku (w pomieszczeniu pochodzącym z XVII wieku) oraz świetlica na parterze. Natomiast na innych kondygnacjach zaprojektowano kotłownię, łaźnię, gabinet lekarsko-dentystyczny, cztery mieszkania, sześć pokoi gościnnych oraz dodatkowe sale: małą (nazwaną salonikiem czerwonym) i dużą ${ }^{43}$. Wykonanie planu wymagało wielu dodatkowych podziałów pomieszczeń, wykuwania nowych otworów drzwiowych i okiennych oraz przesunięcia drzwi ${ }^{44}$. Dokonano także zmian w wystroju wnętrz, które obejmowały m.in.

${ }^{43}$ A. Graczyk, 1971, Projekt koncepcji adaptacji budynku pałacu wraz z planem ogólnym zagospodarowania wokót pałacu w miejscowości Dalków, Zielona Góra, Archiwum Agencji Nieruchomości Rolnych Oddział Terenowy (AANR OT) we Wrocławiu, Wrocław, syg. 49/13, s. 5-6.

${ }^{44}$ Tamże, s. 11-14. 
wykonanie lamperii do wysokości prawie dwóch metrów (w łaźni, pomieszczeniach sanitarnych i kuchennych), pokrycie dwiema warstwami farby olejnej całej stolarki, wymianę zabytkowych balustrad oraz położenie nowego parkietu (zwłaszcza w salach reprezentacyjnych). Tak szeroko zakrojona adaptacja sprawiła, że zatarto oryginalny układ wewnątrz budynku. Zniszczono także zabytkowe elementy architektoniczne oraz ozdobne fragmenty balkonów.

Traktowanie zabytków jak każdego innego budynku i kierowanie się jedynie względami użyteczności sprawiło, że wiele obiektów, które przetrwały wojnę w dobrym stanie, uległo dewastacji lub zostało całkowicie zniszczonych, zanim nastał okres transformacji ustrojowej. Mimo zmian, jakie nastąpiły po 1989 roku w zakresie instytucji odpowiedzialnych za dalsze zachowanie obiektów zabytkowych, reform, którym podlegały służby konserwatorskie, prywatyzacji majątków po byłych PGR-ach oraz polepszających się ogólnych warunków w kraju, zniszczenia w kulturowym obrazie Dolnego Śląska nie zostały zahamowane. Brak środków na prace ratunkowe, w których powinny być uwzględnione niemal wszystkie obiekty zabytkowe regionu, ich duża liczba i brak podstawowych działań edukacyjnych względem potrzeby zachowania dziedzictwa kulturowego sprawiły, że dewastacje budynków nadal miały miejsce. Ponownie w najgorszej sytuacji znalazły się obiekty pozbawione właścicieli podejmujących prace na rzecz remontu zabytku. Zniszczeniu przez ludzi w tym czasie uległ m.in. XVI-wieczny dwór w Wojbórzu. Nieszczelności $\mathrm{w}$ dachu oraz pozrywane rynny i rury spustowe powodowały przenikanie wody opadowej do budynku, a w efekcie zawilgocone zostały elementy konstrukcji dachowej, podłóg i stychu, a piwnice zostały zalane ${ }^{45}$. Zdewastowano również wnętrza, które zasypano śmieciami, pozrywano w nich podłogi, stopnie ze schodów i kamienne obramienia drzwi, rozbito posadzkę w części pomieszczeń oraz rozebrano instalację elektryczną. Kolejnym przykładem była rezydencja w Dzikowcu (gmina Nowa Ruda), w której bezpośrednim otoczeniu mieszkańcy urządzili wysypisko śmieci (przy północnej elewacji budynku) ${ }^{46}$. Pomimo tego, że obiekt był stale użytkowany, jego wnętrza zostały zdewastowane. Zniszczono stolarkę okienną, werandę, posadzki, a duży piec umiejscowiony w kuchni rozebrano. Podobna sytuacja miała miejsce w Stradomii Dolnej (gmina Syców). Jeszcze w latach 90. XX wieku na parterze i piętrze pałacu znajdowało się łącznie dziewięć zamieszkałych lokali i dwa pustostany ${ }^{47}$. Niedługo potem budynek został zdewastowany przez mieszkańców obiektu, którzy do ogrzewania używali m.in. desek podłogowych wyrywanych z niezagospodarowanych pomieszczeń. Złe użytkowanie przenośnych pieców spowodowało rozrywanie kominów, a wszelkie ozdobne elementy pałacu zostały skute

${ }^{45}$ E. Sawińska, 2009, Karta ewidencyjna zabytków architektury i budownictwa, Dwór w Wojbórzu, Wrocław, WUOZ we Wrocławiu, Delegatura w Wałbrzychu, s. 2.

${ }^{46}$ K. Guttmejer, 1994, Karta ewidencyjna zabytków architektury i budownictwa, Dwór w Dzikowcu, Wrocław, WUOZ we Wrocławiu, Delegatura w Wałbrzychu, s. 2.

${ }^{47}$ E. Ratajczak, 1997, Dokumentacja konserwatorska - ekspertyza techniczna konstrukcji pałacu w Stradomii Dolnej, WUOZ we Wrocławiu, Wrocław, s. 6. 
i ukradzione ${ }^{48}$. Od dewastacji nie uchroniono również zabytkowych parków. Po 1945 roku najczęściej wydzielano w nich ogródki i sadzono drzewa owocowe (Tomice, gmina Jordanów), a także nagminnie stawiano w ich obrębie wiaty, szopy i inne małe budynki. W późniejszym okresie powszechnie stawały się one miejscami pozyskiwania drewna opałowego, śmietniskami i składowiskami złomu. Zasypywano lub zanieczyszczano zbiorniki wodne będące wcześniej ozdobami parków, niszczono układ założeń, wyrębywano drzewa i niszczono wyznaczające granice mury. Takie działania przyczyniały się do szybkiej dewastacji terenów otaczających rezydencje i zabytkowe zespoły.

Zrujnowane lub niewłaściwie użytkowane budynki często ulegały spaleniu. Pożary najczęściej (63\% ogólnej liczby) wywoływane były brakiem zachowania podstawowych środków ostrożności. Zaprószenie ogniem powodowane było najczęściej przez nieostrożność ludzi obsługujących urządzenia elektryczne, niewłaściwie prowadzone prace spawalnicze realizowane na terenie obiektu oraz wadliwe, wyeksploatowane, często prowizoryczne instalacje elektryczne i odgromowe ${ }^{49}$. Znaczna liczba pożarów była wynikiem celowego podpalenia (30\%). Ich sprawcami były często osoby postronne, mające dostęp do niezabezpieczonych budynków. Tylko 4\% spłonięć wywołanych było przez czynniki naturalne, takie jak burze i wyładowania atmosferyczne ${ }^{50}$. Biorąc pod uwagę, że przy temperaturze $200^{\circ} \mathrm{C}$ wytrzymałość materiałów murowanych spada o $12-30 \%$, a przy $500^{\circ} \mathrm{C}$ prawie o $50 \%{ }^{51}$, oczywiste jest, że zniszczenia dokonane w wyniku pożarów były często nieodwracalne. $\mathrm{Z}$ omawianych zabytków pożarowi uległy m.in. rezydencje we Włosieniu Dolnym (gmina Platerówka) w 1975 roku $^{52}$, w Trzebicku (gmina Cieszków) w 1979 roku $^{53}$, Ratnie Dolnym (gmina Radków) w 1998 roku $^{54}$ oraz w Leśnej (gmina Leśna) w 2004 roku ${ }^{55}$. W przypadku dwóch pierwszych ogień zniszczył je w sposób niemal uniemożliwiający odbudowę. Pałac we Włosieniu Dolnym został odremontowany przed 1979 rokiem ze środków resortu rolnictwa, jednak w odbudowie zastosowano materiały łatwopalne. Niedługo po tym budynek uległ pożarowi, a PGR Sulików, który był jego właścicielem, nie podjął się już jego zabezpieczenia. Podczas inspekcji konserwa-

48 Tamże.

49 D. Drewniacki, Prawne i organizacyjne aspekty ochrony zabytków (dóbr kultury) na wypadek konfliktu zbrojnego i sytuacji kryzysowych (szczególnych zagrożén) w prawie polskim, Ministerstwo Kultury i Dziedzictwa Narodowego, www.mkidn.gov.pl, s. 1.

50 Tamże.

51 W. Borusiewicz, 1985, Konserwacja zabytków budownictwa murowanego, Warszawa, s. 47.

52 Pismo dotyczące zabytkowego założenia pałacowo-ogrodowego we Włosieniu Dolnym gmina Platerówka z dn. 05.09.1989, Jelenia Góra, AANR OT we Wrocławiu, Wrocław, s. 1.

53 Urząd Gminy Cieszków, http://www.cieszkow.pl/gmina-2/zabytki/pa\%C5\%82ac-w-trzebicku/ (20.07.2016)

54 Zamek w Ratnie Dolnym, http://wroclaw.naszemiasto.pl/artykul/zamek-w-ratnie-dolnym,125067, art,t,id,tm.html (20.07.2016).

${ }_{55}$ Wniosek w sprawie skreślenia pałacu w Leśnej z rejestru zabytków z dnia 11.04.2005, AANR OT we Wrocławiu, Wrocław, syg. 3/148, s. 1-2. 
torskiej w sierpniu 1989 roku stwierdzono, że w spalonym pałacu nie przedsięwzięto żadnych prób odbudowy ${ }^{56}$. Opuszczone budynki gospodarskie niszczały, a park został zamieniony w wysypisko śmieci. Zalecono zagospodarować park oraz odbudować pałac i przeznaczyć go na dom opieki społecznej lub na inne potrzeby służby zdrowia. Do prac jednak nie przystąpiono, a do wojewódzkiego konserwatora zabytków nie wpłynął wniosek o dofinansowanie remontu. Natomiast w Trzebicku spłonęła część poddasza, niszcząc dach i stropy ${ }^{57}$. Wyprowadzono lokatorów i rozpoczęto przygotowania do remontu pałacu, jednak ze względu na stan wojenny żadnych działań w tym kierunku nie podjęto. Opustoszały pałac stał się miejscem pozyskiwania złomu i drewna opałowego, a elementy kamienne i dekoracyjne zostały ukradzione $^{58}$. Zamek w Ratnie Dolnym był już w tym czasie własnością prywatną (od 1996 roku) i Agencja, która wcześniej nim dysponowała, nie podjęła się określenia strat powstałych w wyniku pożaru, zwłaszcza że obiekt przejęła bez elementów wyposażenia o wartości historycznej czy artystycznej ${ }^{59}$. W najbardziej niekorzystnej sytuacji znalazł się obiekt w Leśnej. Pożar po pierwszym ugaszeniu stale się odnawiał i trwał około dwóch miesięcy ${ }^{60}$. Dodatkowo, w efekcie silnych wiatrów i deszczów, zawaliły się kominy i łuki konstrukcyjne ścian pierwszego piętra. Wytrzymałość utraciła znaczna część murów, czego skutkiem było znaczne zużycie techniczne, które określono na 91\%, a koszty prac zabezpieczających wyceniono na prawie 96 tys. $\mathrm{z}^{61}$.

Również w ostatnich latach pożarom uległo kilka obiektów zabytkowych na Dolnym Śląsku. Należał do nich m.in. renesansowy dwór Jastrzębce (gmina Środa Śląska). W 2014 roku część pomieszczeń w tej rezydencji została doszczętnie zniszczona przez ogień, a całość groziła zawaleniem. W 2015 roku spaliło się poszycie dachu, poddasze i część piętra pałacu w Cieszycach (gmina Kobierzyce), spłonął też opuszczony i popadający w ruinę pałac w Golędzinowie (gmina Oborniki Śląskie).

Zniszczeń zabytkowych zasobów Dolnego Śląska dopełniały kradzieże, odnotowywane w dokumentacji Agencji po 1991 roku. Przykładowo na początku lat 90. XX wieku z pałacu w Wiadrowie (gmina Paszowice) ukradziono dwie rzeźby. Natomiast w 1995 roku z ruin rezydencji w Rudnicy (gmina Stoszowice) wykuto portal elewacji głównej i wyniesiono dwa kamienne koryta ${ }^{62}$. W 2001 roku zgłoszono też

${ }^{56}$ Pismo dotyczące zabytkowego założenia pałacowo-ogrodowego we Włosieniu Dolnym...

${ }^{57}$ A. Wilk, 1995, Karta ewidencyjna zabytków architektury i budownictwa, Pałac w Trzebicku, WUOZ we Wrocławiu, Wrocław, s. 2.

${ }^{58}$ Tamże.

${ }^{59}$ Pismo w sprawie pożaru pałacu w Ratnie Dolnym do Komendy Rejonowej Policji w Nowej Rudzie z dnia 3.03.1998, Wrocław, AANR OT we Wrocławiu, Wrocław, s. 1.

${ }^{60}$ Wniosek w sprawie decyzji o skreśleniu z rejestru zabytków pałacu w Leśnej z dnia 11.04.2005 r., Jelenia Góra, AANR OT we Wrocławiu, Wrocław, s. 1-2.

${ }_{61}$ Tamże.

${ }^{62}$ Postanowienie o odmowie wszczęcia postępowania, 1995, Stoszowice, AANR OT we Wrocławiu, Wrocław, s. 1. 


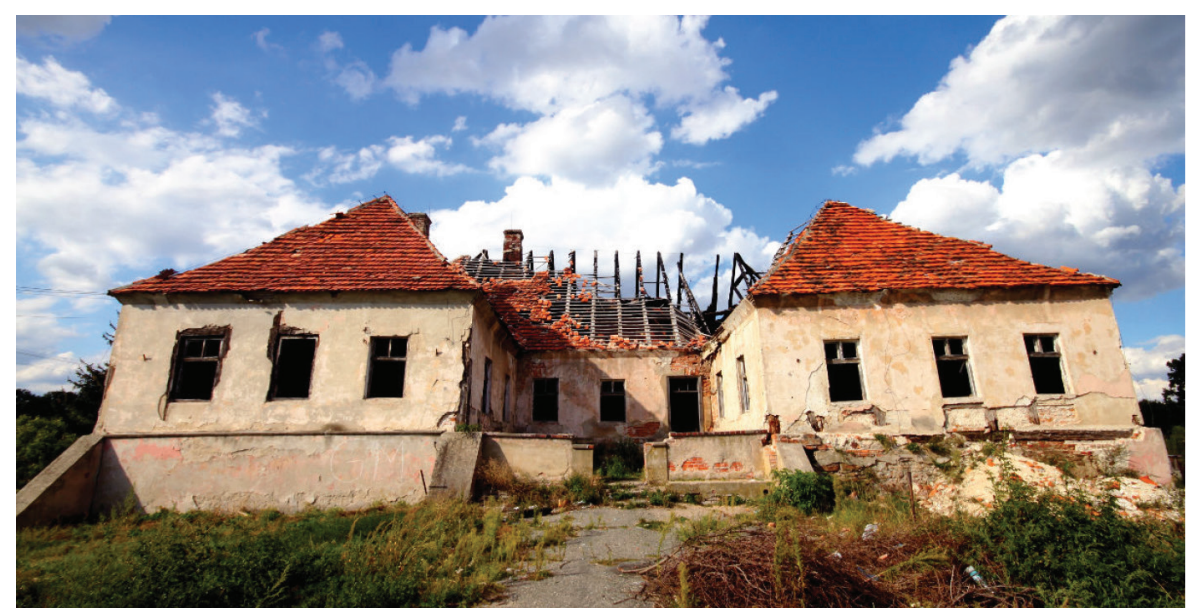

Fot. 2. Dwór w Jastrzębcach po pożarze w 2014 roku Źródło: zbiory własne.

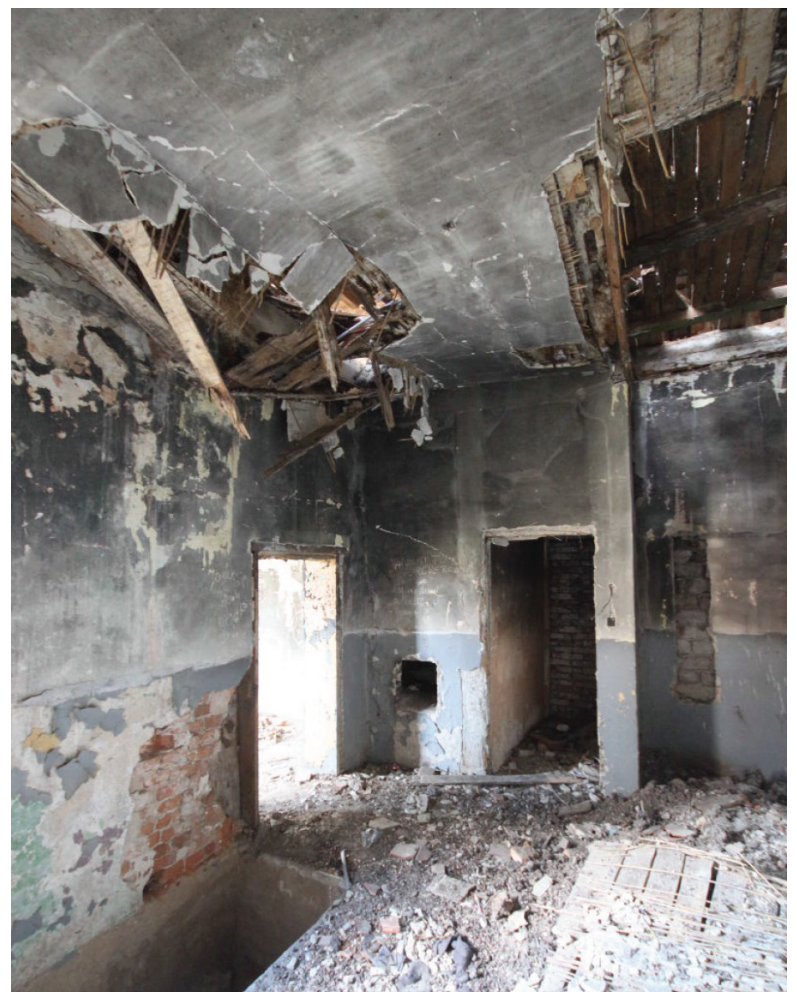

Fot. 3. Wnętrza dworu w Jastrzębcach

Źródło: zbiory własne. 
kradzież żelaznych, XVII-wiecznych drzwi pałacu w Wyszonowicach (gmina Wiązów), których wartość w protokołach zgłoszonego przestępstwa wyceniono jedynie na 2 tys. $z^{63}$. Zrabowane $\mathrm{z}$ opuszczonych zabudowań przedmioty stanowiły najczęściej ostatnie cenne wyposażenie pałaców i dworów.

\section{Wpływ warunków atmosferycznych i przyrodniczych na stan zabytków}

Kolejną przyczyną złego stanu obiektów zabytkowych był wpływ klimatu i warunków atmosferycznych, na które narażone były źle zabezpieczone lub nieużytkowane obiekty. Niebezpieczeństwo dla zabytków stanowiły w największym stopniu powodzie, ale również ulewne deszcze, wichury, wysokie temperatury oraz silne mrozy. $\mathrm{Na}$ te czynniki szczególnie narażone były historyczne obiekty, których znaczne zużycie konstrukcji czy materiału budowlanego czyniło je bardziej podatnymi na zniszczenia. Warunki pogodowe wpływały na deformację i osłabienie bryły, powstawanie rys, szczelin, spękań, a co z tym związane - zmniejszenie wytrzymałości murów. Najbardziej niszcząca była woda i wilgoć. Powodowała ona mechaniczne wypłukiwanie słabszych elementów, rozsadzanie konstrukcji przez zamarzanie wody w szczelinach, korozję elementów stalowych (haki, klamry, kotwy umiejscowione w murach) oraz niszczenie drewnianych elementów konstrukcji ${ }^{64}$. Poważne szkody były także efektem działań wiatrów, które zrywały dachy czy wywracały pozbawione stabilności ściany budynków. Wietrzna pogoda, występująca w Polsce szczególnie w pierwszych trzech i dwóch ostatnich miesiącach roku, była także nośnikiem szkodliwych substancji znajdujących się w powietrzu lub wodzie deszczowej, osadzanych na powierzchni murów i dekoracji. Substancje te, przenikając do wnętrza budynków, niszczyły freski, malowidła oraz elementy wyposażenia ${ }^{65}$.

Niebezpieczne dla zabudowań były także powodzie, szczególnie ze względu na częstotliwość ich występowania. W Polsce na terenach najbardziej zagrożonych podtopieniami, mogącymi występować niemal w każdym miesiącu w roku, znajdowała się infrastruktura 1039 gmin, w tym m.in. ponad 875 tys. ha użytków rolnych, 86,5 tys. budynków mieszkalnych, 2,6 tys. budynków użyteczności publicznej ${ }^{66}$, a pośród nich również zabytkowa architektura. W najgorszej sytuacji pod względem niebezpieczeństwa wystąpienia powodzi były tereny pięciu województw południowych: małopolskiego, podkarpackiego, śląskiego, opolskiego i dolnośląskiego, na których zalania występowały w latach 1945-2001 najczęściej. Spowodowane były one intensywnymi opadami deszczu, gwałtownym topnieniem śniegu, zatorem lodo-

63 Postanowienie o umorzeniu postępowania w sprawie kradzieży drzwi pałacu w Wyszonowicach z dnia 09.08.2001, AANR OT we Wrocławiu, Wrocław, s. 1.

64 W. Borusiewicz, wyd. cyt., s. 40-41.

65 Tamże, s. 38.

${ }^{66}$ Zagrożenia okresowe wystęujące w Polsce, 2010, Warszawa, s. 39. 
wym na rzece albo awarią zbiorników retencyjnych. W wyniku powodzi w lipcu 1997 roku w województwie wrocławskim zalanych zostało 12 kościołów, cztery plebanie, 10 zabytkowych rezydencji, siedem oficyn dworskich i folwarków, 21 parków i dwa zespoły urbanistyczne ${ }^{67}$, natomiast w samym Wrocławiu - obiekty kultury i użyteczności publicznej, 13 kościołów, 23 kamienice i trzy parki ${ }^{68}$. Straty odnotowano m.in. w parku wchodzącym w skład zespołu pałacowego w Gniechowicach (gmina Kąty Wrocławskie). Fala niosąca ze sobą zanieczyszczenia, pochodzące m.in. z zalanych śmietnisk, zniszczyła zabytkowy teren, który do tej pory był miejscem wypoczynku i rekreacji mieszkańców, a jego część stanowił plac zabaw dla dzieci. Najpilniejszym zadaniem było usunięcie naniesionych przez wodę śmieci oraz podjęcie prac porządkowych, które obejmować miały likwidację gałęzi i połamanych lub osłabionych drzew ${ }^{69}$. Park miał podlegać również renowacji oznaczającej w szczególności wprowadzenie nowej zieleni ${ }^{70}$. W lutym 2010 roku obawiano się zalania pałacu Wojanów, ale dzięki pracom polegającym na rozbijaniu lodu na rzece podtopiona została tylko część parku. Natomiast w sierpniu tego roku, w efekcie przerwania zapory w Niedowie, zagrożony był XVIII-wieczny pałac w Radomierzycach (gmina Zgorzelec).

\section{Zakończenie}

Architektura zabytkowa stanowi jeden z najważniejszych walorów Dolnego Śląska Od wielu lat wzrasta zainteresowanie zabytkami, w których dostrzega się element podnoszący atrakcyjność regionu, inwestycyjny, ale też prestiżowy, wynikający z posiadania pałacu, dworu czy zamku jako domu lub siedziby firmy. Przybywa również odnowionych przez liczne fundacje, przedsiębiorstwa i osoby prywatne historycznych rezydencji i folwarków, a co z tym związane, zwiększa się liczba osób zainteresowanych kupnem zabytku, wyremontowaniem go, utrzymaniem i przystosowaniem do nowych funkcji. Rewitalizowane budynki czy zespoły stanowią dowód, że ich współczesne wykorzystanie jest możliwe i może być źródłem dochodu dla właścicieli. Jako przykłady posłużyć mogą obiekty, w których mieszczą się hotele, restauracje i sale konferencyjne, takie jak m.in. zamek na wodzie w Wojnowicach, pałac Alexandrów w Samotworze i pałac w Krobielowicach, ale również te, dostosowane do innych funkcji, na przykład pałac w Pawłowicach, w którym mieści się Regionalne Centrum Kongresowe Uniwersytetu Przyrodniczego we Wrocławiu.

${ }^{67}$ K. Sałaciński, 1998, Straty $w$ dobrach kultury $w$ czasie powodzi-uwagi, spostrzeżenia $i$ wnioski, Ochrona Zabytków, nr 51/1, s. 58.

68 Tamże.

69 Informacja dotycząca szkód wywołanych przez powódź w parku zabytkowym w Gniechowicach, 1997, Wrocław, AANR OT we Wrocławiu, Wrocław, s. 1.

70 Tamże. 


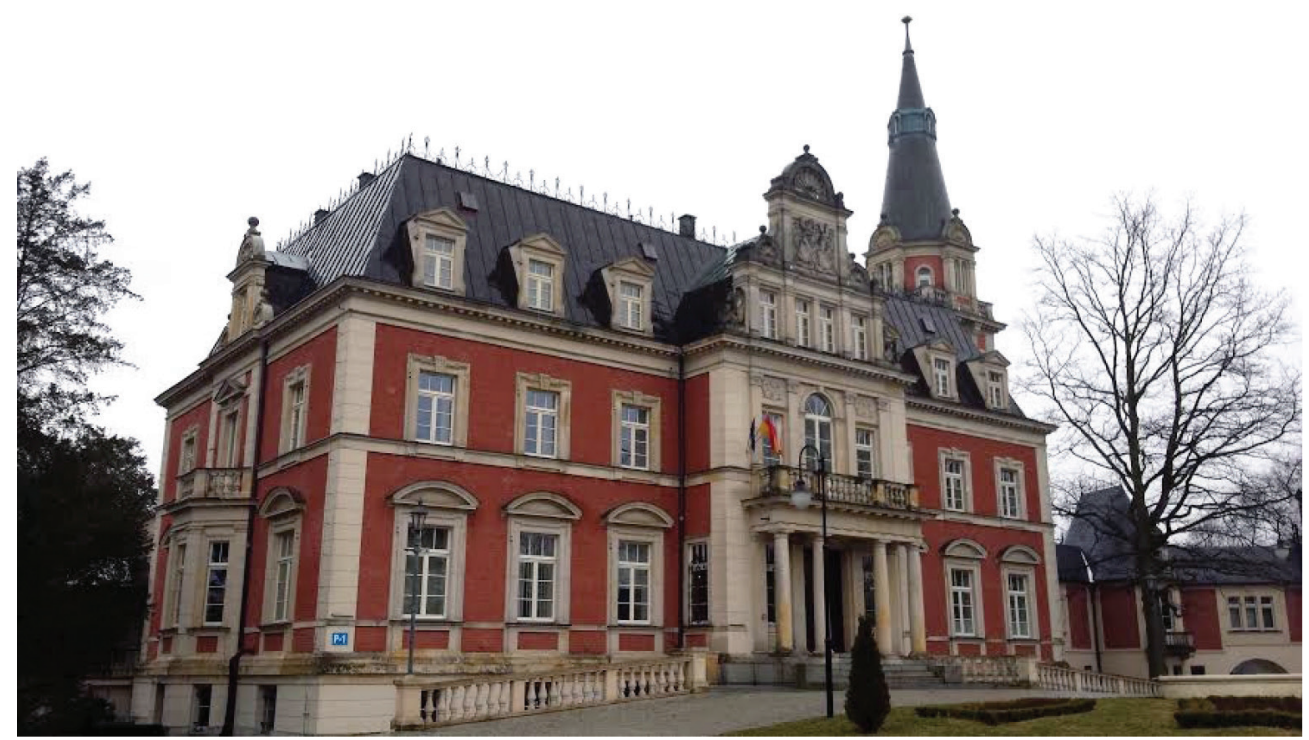

Fot. 4. Pałac w Pawłowicach

Źródło: zbiory własne.

Pośród grupy obiektów zabytkowych za najbardziej stabilne pod względem zachowania uważane są obiekty sakralne i użyteczności publicznej, natomiast za zagrożone uznaje się budynki przemysłowe, mieszkalne oraz zlokalizowane na byłych terenach Państwowych Gospodarstw Rolnych, pozostające jako własność państwa $^{71}$. Mimo pozytywnych kierunków w ochronie dziedzictwa kulturowego, całościowy obraz zachowania obiektów zabytkowych zakłócany jest przez nieruchomości niszczejące, nieobjęte programami rewitalizacji lub pozostawione bez ochrony przez ich właścicieli. Czynniki wpływające na ich pogarszający się stan związane są w pierwszej kolejności z niejasnym prawem, które do momentu przejęcia zabytków do oddziałów Agencji Nieruchomości Rolnych w latach 90. XX wieku nie narzucało odpowiedzialności za ich zachowanie na określone podmioty: instytucje, służby konserwatorskie czy konkretne osoby. Z kolei celem Agencji była sprzedaż jak największej liczby budynków bez weryfikacji przyszłych właścicieli.

Znaczne zniszczenia zabytków wynikały z działalności ludzi, czasem powodowanej brakiem świadomości, bezmyślnością i aktami wandalizmu, ale i często związanej również z bezrobociem, biedą, brakiem możliwości lub chęci podjęcia pracy i nieprzygotowaniem do życia. Te ostatnie czynniki były niejednokrotnie powodami demontażu z historycznych zabytków części drewnianych (przeznaczanych na opał) i metalowych (sprzedawanych na złom), detali architektonicznych, wycinki drzew w zabytkowych ogrodach oraz rozbierania ścian na budulec. Skutki takiej działalności

${ }^{71}$ Raport analizujący stan zabytków nieruchomych, 2003, www.nid.pl (11.03.2016), s. 5. 
potęgowane były przez warunki atmosferyczne, których efektem był stale pogarszający się stan niezabezpieczonych i nieobjętych należytą ochroną obiektów.

Skala i wartość zniszczeń wywołana wymienionymi czynnikami oraz innymi przestępstwami związanymi z zabytkowymi nieruchomościami ${ }^{72}$ jest niemożliwa do oszacowania ze względu na różnorodność obiektów czy trudną do zmierzenia kwestię ich wartości historycznej, estetycznej oraz kulturowej. Należy jednak pamiętać, że zasób ten jest ograniczony. Priorytet jego zachowania i zahamowania niekorzystnych czynników wpływających na pogarszający się stan techniczny budynków powinien wynikać nie tylko z przepisów prawnych, ale również ze społecznej świadomości dziedzictwa kulturowego i zrozumienia jego znaczenia dla społeczeństwa. Równie ważne jest stanowisko władz administracyjnych względem zabytków i uwzględnienie ich w planach rozwoju regionu z korzyścią dla miejscowej ludności i turystów.

\section{Literatura}

Barański M., 1999, Świadomość a ochrona zabytków, [w:] Zabytki i społeczeństwo. Czynnik spoteczny w ochronie zabytków w warunkach reformy samorzadowej, Gutkowska K., Kobyliński Z. (red.), Warszawa.

Borusiewicz W., 1985, Konserwacja zabytków budownictwa murowanego, Warszawa.

Chorowska M., 2003, Rezydencje średniowieczne na Ślasku. Zamki, pałace, wieże mieszkalne, Wrocław.

Czerner O., 1974, W trzydziestolecie powojennej opieki nad zabytkami, Ochrona Zabytków, nr 27/3, s. $171-173$.

Czerner O., 2000, Zabytki Ślaska w Polsce dyktatury proletariatu, [w:] Badania i ochrona zabytków w Polsce w XX wieku: materiaty z konferencji naukowej zorganizowanej staraniem Wydziału Architektury Politechniki Warszawskiej, Generalnego Konserwatora Zabytków i Towarzystwa Opieki nad Zabytkami w stulecie urodzin Profesora Jana Zachwatowicza w dniu 4 marca 2000 roku, Tomaszewski A. (red.).

Czerner O., 2004, Architektury istnienie i zachowanie - z szuflady Profesora, Wrocław, s. 185.

Drewniacki D., Prawne i organizacyjne aspekty ochrony zabytków (dóbr kultury) na wypadek konfliktu zbrojnego i sytuacji kryzysowych (szczególnych zagrożeń) w prawie polskim, Ministerstwo Kultury i Dziedzictwa Narodowego, www.mkidn.gov.pl.

Dutkiewicz J.E., 1964, Dwadzieścia lat ochrony zabytków w Polsce Ludowej, Ochrona Zabytków, nr 17/2.

Gąsior I., 1995, Karta ewidencyjna zabytków architektury i budownictwa. Pałac w Sokolnikach, Wrocław, WUOZ we Wrocławiu, Wrocław.

Godlewski P., 1990, Karta ewidencyjna zabytków architektury i budownictwa, pałac we Wziachowie Małym, WUOZ we Wrocławiu, Wrocław.

Graczyk A., 1971, Projekt koncepcji adaptacji budynku pałacu wraz z planem ogólnym zagospodarowania wokót pałacu w miejscowości Dalków, Zielona Góra, AANR OT we Wrocławiu, Wrocław, syg. 49/13.

72 O. Jakubowski, 2011, Wykorzystanie unormowań art. 95 ustawy o ochronie zabytków i opiece nad zabytkami do walki z przestępczościa przeciwko dziedzictwu narodowemu - propozycje rozwiąań, Opolskie Studia Administracyjno-Prawne VIII, s. 46. 
Gubańska R., 2009, Budynki i budowle dolnośląskich folwarków, Wrocław.

Guttmejer K., 1994, Karta ewidencyjna zabytków architektury i budownictwa, Dwór w Dzikowcu, Wrocław, WUOZ we Wrocławiu, Delegatura w Wałbrzychu.

Informacja dotycząca szkód wywołanych przez powódź w parku zabytkowym w Gniechowicach, 1997, Wrocław, AANR OT we Wrocławiu, Wrocław.

Jakubowski O., 2011, Wykorzystanie unormowań art. 95 ustawy o ochronie zabytków i opiece nad zabytkami do walki z przestępczościa przeciwko dziedzictwu narodowemu - propozycje rozwiazań, Opolskie Studia Administracyjno-Prawne VIII.

Krasocki M., 1955, Dziesięć lat pracy konserwatorskiej w liczbach, Ochrona Zabytków, R. 8, nr 2.

Małachowicz E., 1994, Konserwacja i rewaloryzacja architektury w zespołach i krajobrazie, Wrocław.

Marcinkowska E., Uszałowicz B., 1983, Karta ewidencyjna zabytków architektury i budownictwa, Pałac w Ozorowicach, Wrocław, WUOZ we Wrocławiu, Wrocław.

Merta-Staszczak A., 2014, Rezydencje w procesie zagospodarowania nieruchomości Skarbu Państwa na Dolnym Ślasku w latach 1989-2011, Torun.

Nowak-Obelinda B., 2015, Czy system ochrony i opieki nad zabytkami zapewnia prawidłowe zagospodarowanie i konserwację zabytków nieruchomych w Polsce?, [w:] Zabytek zadbany. Co to zna$c z y$ ?, Liżewska I. (red.), Warszawa.

Obiekty nieruchome wpisane do rejestru zabytków, Narodowy Instytut Dziedzictwa, ww.nid.pl.

Pismo dotyczące zabytkowego założenia pałacowo-ogrodowego we Włosieniu Dolnym gmina Platerówka z dn. 5.09.1989, Jelenia Góra, AANR OT we Wrocławiu, Wrocław.

Pismo w sprawie pożaru pałacu w Ratnie Dolnym do Komendy Rejonowej Policji w Nowej Rudzie z dnia 3.03.1998, Wrocław, AANR OT we Wrocławiu, Wrocław.

Postanowienie o odmowie wszczęcia postępowania, 1995, Stoszowice, AANR OT we Wrocławiu, Wrocław.

Postanowienie o umorzeniu postępowania w sprawie kradzieży drzwi pałacu w Wyszonowicach z dnia 09.08.2001, AANR OT we Wrocłąwiu, Wrocław.

Pruszyński J., 1989, Ochrona zabytków w Polsce, Warszawa, s. 185.

Pruszyński J., 1992, Tradycja i postęp (ochrona zabytków na wsi), Ochrona Zabytków, nr 45/1-2.

Pruszyński J., 1996, Stan i potrzeby regulacji prawnej ochrony zabytków w Polsce, Ochrona Zabytków, nr 49/3.

Przyłęcki M., 1979, Odbudowa, konserwacja i ochrona zabytków architektury na Dolnym Śląsku w latach 1945-1978, Ochrona Zabytków, nr 32/4.

Raport roczny Narodowego Instytutu Dziedzictwa, 2011, Warszawa.

Ratajczak E., 1997, Dokumentacja konserwatorska - ekspertyza techniczna konstrukcji pałacu w Stradomii Dolnej, Wrocław, WUOZ we Wrocławiu, Wrocław.

Sałaciński K., 1998, Straty $w$ dobrach kultury w czasie powodzi - uwagi, spostrzeżenia $i$ wnioski, Ochrona Zabytków, nr 51/1.

Sawińska E., 2009, Karta ewidencyjna zabytków architektury i budownictwa, Dwór w Wojbórzu, Wrocław, WUOZ we Wrocławiu, Delegatura w Wałbrzychu.

Stenogram narady kierowniczej kadry kulturalnej województwa wrocławskiego, Wrocław 1972, Archiwum Państwowe we Wrocławiu, Prezydium WRN we Wrocławiu, syg. IX/8.

Świerczyński J., 1986, Grabieżcy kultury i fatszerze sztuki, Warszawa.

Uchwała nr 417 Rady Ministrów z dnia 8 grudnia 1960 r. w sprawie zakończenia prac związanych z usuwaniem pozostałości zniszczeń wojennych.

Uchwała nr 666 Prezydium Rządu z dnia 20 sierpnia 1955 r. w sprawie planowanej akcji usunięcia pozostałości zniszczeń wojennych w miastach i osiedlach.

Urząd Gminy Cieszków, http://www.cieszkow.pl/gmina-2/zabytki/pa\%C5\%82ac-w-trzebicku (20.07.2016). 
Ustawa o ochronie dóbr kultury, Dz.U. 1962 nr 10, poz. 48.

Ustawa o ochronie zabytków i opiece nad zabytkami, Dz.U. 2003 nr 161, poz. 1568.

Wilk A., 1995, Karta ewidencyjna zabytków architektury i budownictwa, Pałac w Trzebicku, Wrocław, WUOZ we Wrocławiu, Wrocław.

Wniosek w sprawie decyzji o skreśleniu z rejestru zabytków pałacu w Leśnej z dnia 11.04.2005 r., Jelenia Góra, AANR OT we Wrocławiu, Wrocław.

Wniosek w sprawie skreślenia pałacu w Leśnej z rejestru zabytków z dnia 11.04.2005, AANR OT we Wrocławiu, Wrocław, syg. 3/148.

Zagrożenia okresowe wystęujace w Polsce, 2010, Warszawa.

Zamek w Ratnie Dolnym, http://wroclaw.naszemiasto.pl/artykul/zamek-w-ratnie-dolnym,125067, art,t,id,tm.html (20.07.2016). 